\title{
Two new yeasts, Trichosporon debeurmannianum sp. nov. and Trichosporon dermatis sp. nov., transferred from the Cryptococcus humicola complex
}

\author{
1 Department of \\ Microbiology, Meiji \\ Pharmaceutical University, \\ 2-522-1 Noshio, Kiyose, \\ Tokyo 204-8588, Japan \\ 2 Japan Collection of \\ Microorganisms, RIKEN \\ (The Institute of Physical \\ and Chemical Research), \\ 2-1 Hirosawa, Wako, \\ Saitama 351-0198, Japan
}

\author{
Takashi Sugita, ${ }^{1}$ Masako Takashima, ${ }^{2}$ Takashi Nakase, ${ }^{2} \dagger$ \\ Tomoe Ichikawa, ${ }^{1}$ Reiko Ikeda ${ }^{1}$ and Takako Shinoda ${ }^{1}$
}

Author for correspondence: Takashi Sugita. Tel: +81424 95 8762. Fax: +81 424958762. e-mail: sugita@my-pharm.ac.jp

\begin{abstract}
Cryptococcus humicola, as currently defined, shows intraspecific rRNA gene sequence differences. Three strains of this species produced arthroconidia on cornmeal agar and belonged to the genus Trichosporon in a molecular phylogeny. They clustered with the species possessing Q10 as the major ubiquinone and were serotype $I$. Sequence analyses clearly revealed that they were two new Trichosporon species. The names Trichosporon dermatis sp. nov. (= CBS 2043') and Trichosporon debeurmannianum sp. nov. (= CBS 1896') are proposed for these strains.
\end{abstract}

Keywords: Trichosporon debeurmannianum sp. nov., Trichosporon dermatis sp. nov., rDNA

\section{INTRODUCTION}

Basidiomycetous anamorphic yeasts of the genus Trichosporon Behrend are characterized by the production of arthroconidia, the possession of ubiquinone Q9 or Q10 and the presence of xylose in the cell wall. Approximately 20 species have been described in the genus (Guého et al., 1992; Sugita et al., 1995a; Sugita \& Nakase, 1998a; Middelhoven et al., 1999, 2000). Sugita \& Nakase (1998b) and Fell et al. (2000) reported that the genus Trichosporon was monophyletic on the basis of $18 \mathrm{~S}$ and $28 \mathrm{~S}$ (D1/D2 regions) rDNA sequences, and each cluster correlated well with the molecular type of ubiquinone. Specifically, of three main clusters, one consists of the species possessing Q10 and the remaining two possess Q9. Serologically, there are four serotypes, I, II, III and I-III, in the genus Trichosporon (Ikeda et al., 1996; Nishiura et al., 1997). Serotype I-III species react to both antisera I and III. These serotypes also correlate well with the clusters on the tree.

\footnotetext{
† Present address: Yothi Research Unit, National Center for Genetic Engineering and Biotechnology (BIOTEC), National Science and Technology Development Agency, 73/1 Rama VI Road, Bangkok 10400, Thailand.

The GenBank accession numbers for the 28S rDNA D1/D2 sequences of Trichosporon debeurmannianum sp. nov. and Trichosporon dermatis sp. nov. are $A B 044568$ and $A B 044569$, respectively.
}

While investigating the intraspecies diversity of Cryptococcus humicola, we found three strains that belong to the genus Trichosporon. This paper describes two new yeasts, Trichosporon dermatis sp. nov. and Trichosporon debeurmannianum sp. nov., proposed for these strains.

\section{METHODS}

Strains examined. Strains CBS $1896^{\mathrm{T}}, 1897$ and $2043^{\mathrm{T}}$ were purchased from Centraalbureau voor Schimmelcultures (CBS) as Cryptococcus humicola. The first two were isolated from the bronchial secretions of a man and the latter from an infected human skin lesion (http://www.cbs.knaw.nl/ search_ydb.html).

Morphological, biochemical and physiological characteristics. Most of the morphological, biochemical and physiological characteristics were examined using the methods described by Yarrow (1998). Biochemical characteristics were also investigated using ID32C (bioMérieux) in accordance with the manufacturer's instructions.

Examination of chemotaxonomic characteristics. Extraction, purification and identification of ubiquinones were carried out according to the method of Sugita et al. (1999). The DNA base composition $(\mathrm{mol} \% \mathrm{G}+\mathrm{C})$ was determined by nucleotide analysis, using HPLC after digesting the DNA with Nuclease P1 (Yamasa Shouyu) as described by Sugita et al. (1994). Xylose in cell wall polysaccharide was detected by GC. Cells were collected in $0.02 \mathrm{M}$ sodium citrate buffer (pH 7.0) and autoclaved at $121^{\circ} \mathrm{C}$ for $90 \mathrm{~min}$. Cell wall polysaccharide was precipitated from the supernatant by 


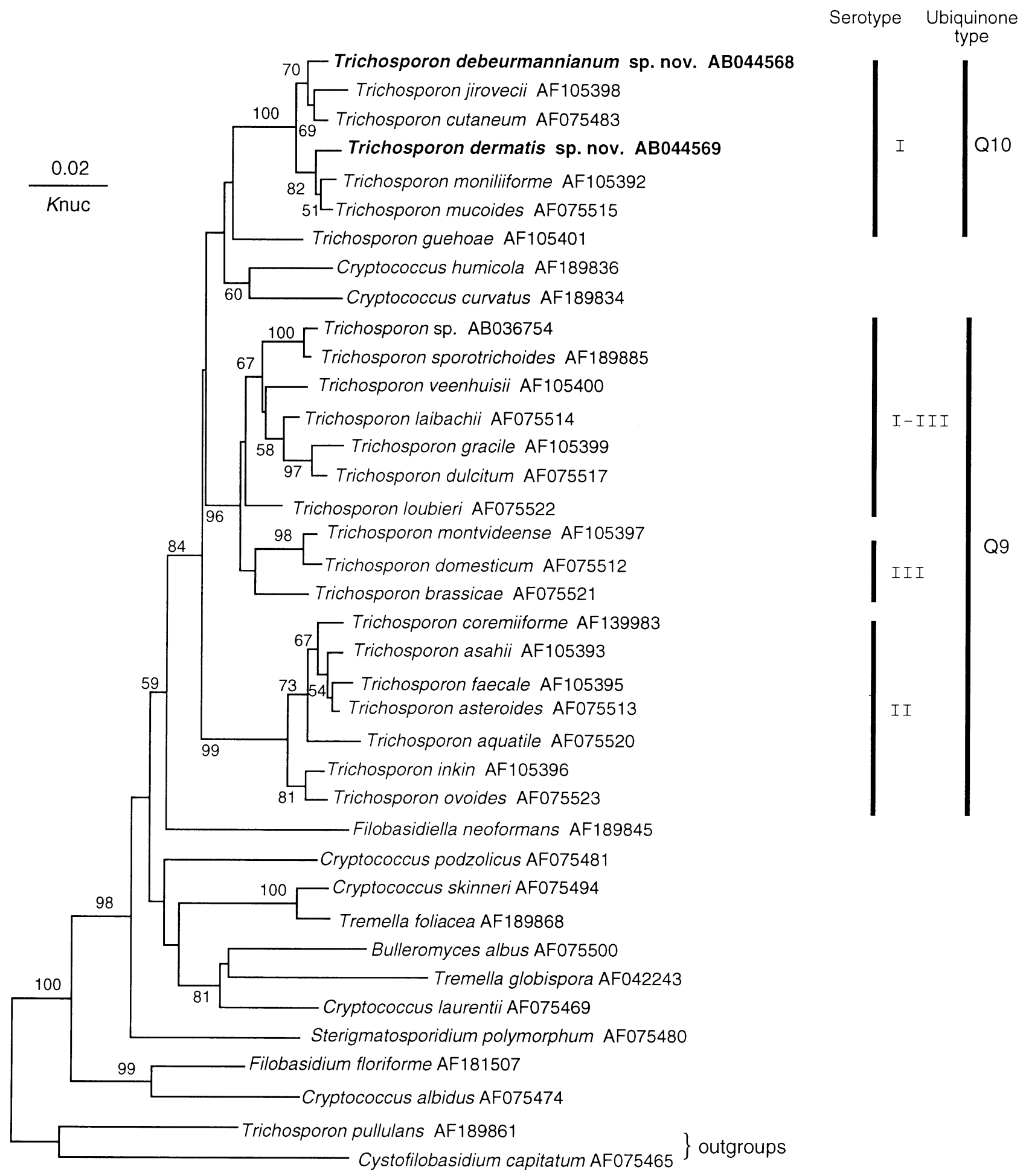

Fig. 1. Neighbour-joining tree of Trichosporon debeurmannianum sp. nov., T. dermatis sp. nov. and related species based on the D1/D2 regions of $28 \mathrm{~S}$ rDNA sequences. The numerals represent percentages from 100 replicate bootstrap samplings (values less than $50 \%$ are not shown). The serotype and major ubiquinone type of the Trichosporon species are also indicated. $K_{\text {nuc }}$ Kimura's parameter (Kimura, 1980).

adding 2 vols ethanol. The precipitate was dissolved, dialysed against water and lyophilized. The polysaccharide was hydrolysed in $2 \mathrm{M}$ trifluoroacetic acid at $120^{\circ} \mathrm{C}$ for $3 \mathrm{~h}$. The hydrolysate was analysed by TLC on silica gel plates with an n-butanol/ethanol/water (40:11:19, by vol.) solvent system. The hydrolysate was reduced with $\mathrm{NaBH}_{4}$ and then acetylated with acetic anhydride/pyridine (1:1, v/v). Alditol acetate was analysed with a Shimadzu gas chromatograph GC-7 in a Gas Chrom Q glass column containing 3\% ECNSS-S (Shinwa) at $190{ }^{\circ} \mathrm{C}$. 
Table 1. Biochemical characteristics of $T$. debeurmannianum sp. nov., T. dermatis sp. nov. and other Q10-serotype I species by ID $32 \mathrm{C}$

+ , Positive; v, variable; -, negative.

\begin{tabular}{|c|c|c|c|c|c|c|}
\hline Compound & $\begin{array}{l}\text { T. debeurmannianum } \\
\text { sp. nov. }\end{array}$ & $\begin{array}{l}\text { T. dermatis } \\
\text { sp. nov. }\end{array}$ & T. cutaneum & T. mucoides & T. jirovecii & T. moniliiforme \\
\hline D-Galactose & - & + & + & + & + & + \\
\hline Cycloheximide $(0.01 \%)$ & + & + & - & + & + & + \\
\hline Sucrose & + & + & + & + & + & + \\
\hline$N$-Acetylglucosamine & + & + & + & + & + & + \\
\hline DL-Lactate & + & + & + & + & + & + \\
\hline L-Arabinose & + & + & + & + & + & + \\
\hline Cellobiose & + & + & $\mathrm{v}$ & + & $\mathrm{v}$ & + \\
\hline Raffinose & + & + & $\mathrm{v}$ & + & + & + \\
\hline Maltose & + & + & + & + & $\mathrm{v}$ & + \\
\hline Trehalose & + & + & $\mathrm{v}$ & + & + & + \\
\hline 2-Keto-D-gluconate & + & + & + & + & + & + \\
\hline$\alpha$-Methyl-D-glucoside & + & + & + & + & $\mathrm{v}$ & + \\
\hline Mannitol & + & + & + & + & $\mathrm{v}$ & + \\
\hline Lactose & + & + & + & + & + & + \\
\hline Inositol & + & + & + & + & + & + \\
\hline Sorbitol & + & + & + & + & - & + \\
\hline D-Xylose & + & + & + & + & + & + \\
\hline D-Ribose & + & + & + & + & + & + \\
\hline Glycerol & + & + & + & + & + & + \\
\hline L-Rhamnose & + & + & $\mathrm{v}$ & $\mathrm{v}$ & $\mathrm{v}$ & + \\
\hline Palatinose & + & + & + & + & $\mathrm{v}$ & + \\
\hline Erythritol & + & + & + & + & + & + \\
\hline Melibiose & + & + & $\mathrm{v}$ & $\mathrm{v}$ & + & + \\
\hline Glucuronate & + & + & + & + & + & + \\
\hline Melezitose & - & + & + & + & + & + \\
\hline Glucuruonate & + & + & + & + & + & + \\
\hline Laevulinate & - & - & - & - & - & - \\
\hline Glucose & + & + & + & + & + & + \\
\hline Sorbose & - & + & - & $\mathrm{v}$ & + & - \\
\hline Glucosamine & + & + & $\mathrm{v}$ & + & + & + \\
\hline Aesculin & + & + & + & + & - & + \\
\hline
\end{tabular}

Direct DNA sequencing. Nuclear DNA was extracted by the method of Makimura et al. (1994). The D1/D2 regions of 28S rDNA were directly determined using PCR products with the primers NL-1 (5'-GCATATCAATAAGCGGAGGAAAAG) and NL-4 (5'-GGTCCGTGTTTCAAGACGG) (Kurtzman \& Robnett, 1997). The PCR products were sequenced with an ABI PRISM Cycle Sequencing kit (Perkin-Elmer Applied Biosystems).

Molecular phylogenetic analysis. The sequences were aligned with the computer program CLUSTAL W, version 1.8 (Thompson et al., 1994). The evolutionary distance for the neighbour-joining method (Saitou \& Nei, 1987) was calculated according to Kimura (1980). Sites where gaps existed in any sequences were excluded. A bootstrap analysis was conducted with 100 replications (Felsenstein, 1985).

In vitro susceptibility tests. The MICs of amphotericin B, 5fluorocytosine, fluconazole, itraconazole and miconazole were determined using an Eiken kit (Eiken Chemical) in accordance with the manufacturer's instructions.

\section{RESULTS AND DISCUSSION}

We previously reported that strains CBS $1896^{\mathrm{T}}$ and 1897 (T. debeurmannianum) and $2043^{\mathrm{T}}$ (T. dermatis) used in this study were positioned in the lineage Trichosporon cutaneum-Trichosporon mucoides in a phylogenetic tree based on the sequences of $18 \mathrm{~S}$ rDNA (Sugita et al., 2000). They possess Q10 as the major ubiquinone and are serotype I. T. cutaneum, Trichosporon jirovecii, Trichosporon moniliiforme and $T$. mucoides also have the same ubiquinone type and serotype as $T$. debeurmannianum and $T$. dermatis. These six species formed a cluster with high bootstrap value $(99 \%)$ on a tree constructed using 18S rDNA sequences (Sugita et al., 2000). In this study, the D1/2 regions of $28 \mathrm{~S}$ rDNA were also sequenced. These six species again formed a single cluster on the tree with a $100 \%$ bootstrap value (Fig. 1). Sugita et al. (1999) demonstrated a relationship between internal trans- 
Table 2. In vitro susceptibility of $T$. debeurmannianum and $T$. dermatis to antifungal agents

AMPH, amphotericin B; 5-FC, 5-fluorocytosine; FLCZ, fluconazole; ITZ, itraconazole; MCZ, miconazole.

\begin{tabular}{|c|c|c|c|c|c|c|}
\hline \multirow[t]{2}{*}{ Species } & \multirow[t]{2}{*}{ Strain } & \multicolumn{5}{|c|}{$\operatorname{MIC}\left(\mu \mathrm{g} \mathrm{ml}^{-1}\right)$} \\
\hline & & АМРН & 5-FC & FLCZ & ITZ & MCZ \\
\hline \multirow[t]{2}{*}{ T. debeurmannianum } & CBS $1896^{\mathrm{T}}$ & $0 \cdot 125$ & $>64$ & 2 & $0 \cdot 06$ & $<0.06$ \\
\hline & CBS 1897 & $0 \cdot 25$ & $>64$ & 4 & $0 \cdot 125$ & $<0.06$ \\
\hline T. dermatis & CBS $2043^{\mathrm{T}}$ & $0 \cdot 25$ & $>64$ & 4 & $0 \cdot 5$ & $0 \cdot 25$ \\
\hline
\end{tabular}
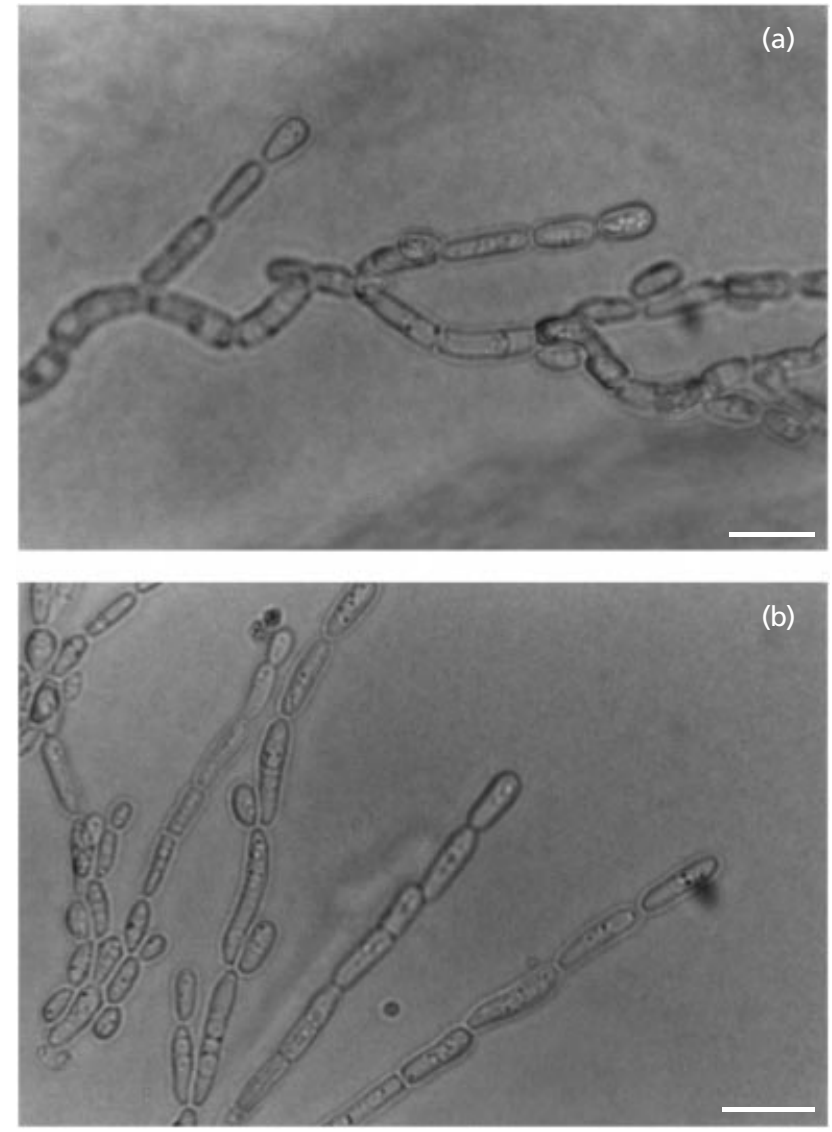

Fig. 2. Arthroconidia of Trichosporon debeurmannianum sp. nov. (a) and $T$. dermatis sp. nov. (b) produced on cornmeal agar after growth for $3 \mathrm{~d}$ at $25^{\circ} \mathrm{C}$. Bars, $10 \mu \mathrm{m}$.

cribed spacer (ITS) sequence similarity and nuclear DNA relatedness and found that conspecific strains differed by fewer than $1 \%$ of nucleotides in the ITS 1 and ITS2 regions overall. Compared to serotype I species, the two new species showed 89.4-99.1\% similarity to ITS1 and $88 \cdot 6-99 \cdot 4 \%$ to ITS2. Overall, the ITS regions show $89 \cdot 4-97 \cdot 1 \%$ similarity among Q10-serotype I species. From these overall ITS similarities, it was concluded that these strains are two new species.
For rapid differentiation of Q10-serotype I species, the commercially available ID32C kit was used. The new species can be differentiated from known Q10-serotype I species on the basis of ability to assimilate galactose, sorbitol, melezitose, sorbose and aesculin, and resistance to $0.01 \%$ cycloheximide (Table 1 ).

Trichosporon is a medically relevant genus that includes the causative agents of deep-seated and superficial infections, including white piedra. Trichosporon species are also involved in summer-type hypersensitivity pneumonitis (SHP). Six species are responsible for these infections and allergies, and the causative agent of trichosporonosis differs in each type of infection (Herbrecht et al., 1993; Guého et al., 1994; Sugita et al., 1995b). Trichosporon asahii and $T$. mucoides are involved in deep-seated infections and are the major causative antigens of SHP (Nishiura et al., 1997). Trichosporon asteroides and T. cutaneum are associated with superficial infections. The appressoriaforming yeasts Trichosporon ovoides and Trichosporon inkin are responsible for white piedra of the head and genital area, respectively. These six medically relevant species are serotype I or II. Serotypes III and I-III do not seem to be responsible for infection or allergy. The three strains examined in this study are serotype I. Both new species proved to be resistant to the antifungal agent 5-fluorocytosine (Table 2). The in vitro susceptibilities of the two new species to the five agents in Table 2 are similar to those of the other six pathogenic Trichosporon species (Guého et al., 1994). Strains CBS $1896^{\mathrm{T}}$ and 1897 were isolated from human bronchial secretions and strain CBS $2043^{\mathrm{T}}$ from an infected human skin lesion. However, it is unknown whether these two species are pathogenic to humans.

\section{Latin diagnosis of Trichosporon debeurmannianum Sugita, Takashima, Nakase et Shinoda sp. nov.}

In liquido ' $Y M$ ', post dies 3 ad $25^{\circ} \mathrm{C}$, cellulae vegetativae ovoideae, ellipsoideae vel elongatae (2$8 \times 2-15 \mu \mathrm{m})$, singulae, binae, in catenis aut in fasciculis, propagantes gemmarum blasticarum. Sedimentum formatur. Post unum mensem ad $17^{\circ} \mathrm{C}$, pellicula fragilis et incompleta aut completa et sedimentum formantur. In agaro ' $Y M$ ', post unum mensem ad $17^{\circ} \mathrm{C}$, cultura pallida aut xanthoalba, glabra aut rugosa, nitida, 
Table 3. Physiological and chemotaxonomic characterization of $T$. debeurmannianum sp. nov. and $T$. dermatis sp. nov.

+, Positive; D, delayed positive; Dw, delayed and weakly positive; w, weakly positive; s, slow positive; -, negative.

\begin{tabular}{|c|c|c|}
\hline Character & $\begin{array}{c}\text { T. debeurmannianum } \\
\text { sp. nov. }\end{array}$ & $\begin{array}{l}T . \text { dermatis } \\
\text { sp. nov. }\end{array}$ \\
\hline \multicolumn{3}{|c|}{ Fermentation of carbon compounds } \\
\hline D-Glucose & - & - \\
\hline \multicolumn{3}{|c|}{ Assimilation of carbon compounds } \\
\hline D-Glucose & + & + \\
\hline D-Galactose & - & + \\
\hline L-Sorbose & DW & + \\
\hline Sucrose & + & + \\
\hline Maltose & + & + \\
\hline Cellobiose & + & + \\
\hline$\alpha, \alpha$-Trehalose & $+/ \mathrm{s}$ & + \\
\hline Lactose & $+/ \mathrm{w}$ & + \\
\hline Melibiose & + & + \\
\hline Raffinose & + & + \\
\hline Melezitose & $\mathrm{W} / \mathrm{DW}$ & + \\
\hline Inulin & $-/ \mathrm{DW}$ & - \\
\hline Soluble starch & + & + \\
\hline D-Xylose & + & + \\
\hline L-Arabinose & $+/ \mathrm{DW}$ & + \\
\hline D-Arabinose & $+/ \mathrm{DW}$ & + \\
\hline D-Ribose & + & + \\
\hline L-Rhamnose & + & + \\
\hline D-Glucosamine & DW & + \\
\hline$N$-Acetyl-D-glucosamine & + & + \\
\hline Methanol & - & - \\
\hline Ethanol & $+/ \mathrm{DW}$ & + \\
\hline Glycerol & + & + \\
\hline Erythritol & $+/ \mathrm{D}$ & + \\
\hline Ribitol & $+/ D$ & + \\
\hline Galactitol & - & DW \\
\hline D-Mannitol & $+/ \mathrm{D}$ & + \\
\hline D-Glucitol & $+/ \mathrm{D}$ & + \\
\hline$\alpha$-Methyl-D-glucoside & + & + \\
\hline Salicin & + & + \\
\hline Glucono- $\delta$-lactone & - & + \\
\hline D-Gluconic acid & + & + \\
\hline 2-Ketogluconic acid & + & + \\
\hline 5-Ketogluconic acid & + & + \\
\hline DL-Lactic acid & + & + \\
\hline Succinic acid & + & + \\
\hline Citric acid & + & + \\
\hline Inositol & + & + \\
\hline n-Hexadecane & - & - \\
\hline Saccharic acid & - & w \\
\hline Xylitol & S/DW & + \\
\hline L-Arabinitol & - & + \\
\hline 1,2-Propanediol & + & + \\
\hline 2,3-Butanediol & $\mathrm{s} /-$ & DW \\
\hline D-Glucuronic acid & + & + \\
\hline D-Galacturonic acid & $+/ \mathrm{DW}$ & + \\
\hline \multicolumn{3}{|c|}{ Assimilation of nitrogen compounds } \\
\hline Ammonium sulfate & + & + \\
\hline Nitrate & - & - \\
\hline
\end{tabular}


Table 3 (cont.)

\begin{tabular}{|c|c|c|}
\hline Character & $\begin{array}{c}\text { T. debeurmannianum } \\
\text { sp. nov. }\end{array}$ & $\begin{array}{l}\text { T. dermatis } \\
\text { sp. nov. }\end{array}$ \\
\hline Nitrite & $\mathrm{W}$ & + \\
\hline Ethylamine hydrochloride & + & + \\
\hline L-Lysine & + & + \\
\hline Cadaverine & + & + \\
\hline \multicolumn{3}{|l|}{ Growth at: } \\
\hline $30{ }^{\circ} \mathrm{C}$ & + & + \\
\hline $35^{\circ} \mathrm{C}$ & + & + \\
\hline $37^{\circ} \mathrm{C}$ & - & + \\
\hline $40{ }^{\circ} \mathrm{C}$ & - & - \\
\hline \multicolumn{3}{|l|}{ Cycloheximide resistance } \\
\hline $0 \cdot 01 \%$ & + & + \\
\hline $0 \cdot 1 \%$ & - & + \\
\hline Production of starch-like substances & - & - \\
\hline Growth on $50 \%(\mathrm{w} / \mathrm{w})$ glucose-yeast extract agar & - & - \\
\hline Urease reaction & + & + \\
\hline Diazonium Blue B reaction & + & + \\
\hline Liquefaction of gelatin & - & - \\
\hline $\mathrm{G}+\mathrm{C}$ content of nuclear DNA ( $\mathrm{mol} \%)$ & $59 \cdot 8$ & $60 \cdot 3$ \\
\hline Major ubiquinone & Q10 & Q10 \\
\hline Xylose in the cell wall & Present & Present \\
\hline
\end{tabular}

butyracea et margine glabra. Arthroconidiorum et mycelium formantur. Fermentatio nulla. D-Glucosum, L-sorbosum (lente et infirme), saccharosum, maltosum, cellobiosum, trehalosum (lente), lactosum (infirme), melibiosum, raffinosum, melezitosum (infirme vel lente et infirme), inulinum (lente et infirme), amylum solubile, D-xylosum, L-arabinosum (lente et infirme), $D$ arabinosum (lente et infirme), D-ribosum, L-rhamnosum, D-glucosaminum (lente et infirme), N-acetylglucosaminum, ethanolum (lente et infirme), glycerolum, erythritolum (lente), ribitolum (lente), D-mannitolum (lente), D-glucitolum (lente), $\alpha$-methyl-D-glucosidum, salicinum, acidum D-gluconicum, acidum 2-ketogluconicum, acidum 5-ketogluconicum, acidum DL-lacticum, acidum succinicum, acidum citricum, inositolum, xylitorum (lente et infirme), 1,2-propanediolum, 2,3-butanediolum (lente), acidum D-glucuronicum, et acidum D-galacturonicum (lente et infirme) assimilantur, autem $D$-galactosum, methanolum, galactitolum, glucono- $\delta$ lactonum, n-hexadecanum, acidium D-saccharicum et L-arabinitolum non assimilantur. Ammonium sulfatum, kalium nitricum (infirme), ethylaminum, L-lysinum et cadaverinum assimilantur, natrium nitrosum non assimilatur. Typus: CBS $1896^{\mathrm{T}}$, Centraalbureau voor Schimmelcultures, Delphi, Batavorum.

\section{Description of Trichosporon debeurmannianum Sugita, Takashima, Nakase et Shinoda sp. nov.}

Trichosporon debeurmannianum (de.beur.man.ni. a'num. M.L. n. debeurmannianum in honour of L. De Beurmann, who described Oidium cutanum
(= Trichosporon cutaneum) and reported it to be a causative agent of superficial fungal infection).

After $3 \mathrm{~d}$ growth in YM broth at $25^{\circ} \mathrm{C}$, the vegetative cells are ovoid, ellipsoid and elongate $(2-8 \times 2-15 \mu \mathrm{m})$, and single, paired or in clusters. Cells reproduce by budding. Sediment is formed. After 1 month growth in YM broth at $17^{\circ} \mathrm{C}$, an incomplete or complete fragile pellicle and sediment are present. After 1 month growth on YM agar at $17^{\circ} \mathrm{C}$, streak cultures are pale to yellowish white, semi-shiny, smooth and wrinkled near the bottom, butyrous, and have an entire and sporadically fringed margin. After $3 \mathrm{~d}$ in Dalmau plate culture on cornmeal agar at $25^{\circ} \mathrm{C}$, arthroconidia and mycelia are produced (Fig. 2a). For physiological and chemotaxonomic characteristics, see Table 3. The type strain is CBS $1896^{\mathrm{T}}$; it was isolated from the bronchial secretions of a man in Utrecht, The Netherlands, and deposited in the Centraalbureau voor Schimmelcultures (CBS) by Swierenga in June 1954. The other strain, CBS 1897, has also been maintained in the CBS.

\section{Latin diagnosis of Trichosporon dermatis Sugita, Takashima, Nakase et Shinoda sp. nov.}

In liquido ' $Y M$ ', post dies 3 ad $25^{\circ} \mathrm{C}$, cellulae vegetativae ovoideae, ellipsoideae vel elongatae (2$8 \times 2-15 \mu \mathrm{m})$, singulae, binae, in catenis aut in fasciculis, propagantes gemmarum multilateraliter. Sedimentum formatur. Post unum mensem ad $17^{\circ} \mathrm{C}$, pellicula fragilis et tenuis, et sedimentum formantur. In agaro 'YM', post unum mensem ad $17^{\circ} \mathrm{C}$, cultura xanthoalba, rugosa, nitida, butyracea et margine mycelica. Arthroconidiorum et mycelium formantur. Ferm- 
entatio nulla. D-Glucosum, D-galactosum, L-sorbosum, saccharosum, maltosum, cellobiosum, trehalosum, lactosum, melibiosum, raffinosum, melezitosum, amylum solubile, D-xylosum, L-arabinosum, D-arabinosum, D-ribosum, L-rhamnosum, D-glucosaminum, $N$-acetylglucosaminum, ethanolum, glycerolum, erythritolum, ribitolum, galactitolum (lente et infirme), D-mannitolum, D-glucitolum, $\alpha$-methyl-D-glucosidum, salicinum, glucono- $\delta$-lactonum, acidium D-gluconicum, acidum 2-ketogluconicum, acidum 5-ketogluconicum, acidum DL-lacticum, acidum succinicum, acidum citricum, inositolum, acidum D-saccharicum (infirme), xylitolum, L-arabinitolum, 1,2-propanediolum, 2,3-butanediolum (lente et infirme), acidum D-glucuronicum et acidum D-galacturonicum assimilantur, autem inulinum, methanolum et $n$-hexadecanum non assimilantur. Ammonium sulfatum, kalium nitricum, ethylaminum, L-lysinum et cadaverinum assimilantur, natrium nitrosum non assimilatur. Typus: CBS 2043 ${ }^{\mathrm{T}}$, Centraalbureau voor Schimmelcultures, Delphi, Batavorum.

\section{Description of Trichosporon dermatis Sugita, Takashima, Nakase et Shinoda sp. nov.}

Trichosporon dermatis (der.ma'tis. Gr. n. dermatis pertaining to skin, from which the organism was isolated).

After $3 \mathrm{~d}$ growth in $\mathrm{YM}$ broth at $25^{\circ} \mathrm{C}$, the vegetative cells are ovoid, ellipsoid and elongate $(2-8 \times 2-15 \mu \mathrm{m})$, and single, paired or in clusters. They reproduce by multilateral budding. Sediment is formed. After 1 month growth in $\mathrm{YM}$ broth at $17^{\circ} \mathrm{C}$, a thin fragile pellicle and thick sediment are present. After 1 month growth on YM agar at $17^{\circ} \mathrm{C}$, streak cultures are yellowish white, semi-shiny, wrinkled, butyrous and have a fringed margin. After $3 \mathrm{~d}$ in Dalmau plate culture on cornmeal agar at $25^{\circ} \mathrm{C}$, arthroconidia and mycelia are produced (Fig. 2b). For physiological and chemotaxonomic characteristics, see Table 3 . The type strain is CBS $2043^{\mathrm{T}}$; it was isolated from infected human skin in Tübingen, Germany, and deposited in the Centraalbureau voor Schimmelcultures (CBS) by Schmitz in December 1954.

\section{ACKNOWLEDGEMENTS}

We thank Dr Robert of the Centraalbureau voor Schimmelcultures for providing information on the strains used in this study.

\section{REFERENCES}

Fell, J. W., Boekhout, T., Fonseca, A., Scorzetti, G. \& StatzellTallman, A. (2000). Biodiversity and systematics of basidiomycetous yeasts as determined by large-subunit rDNA D1/D2 domain sequence analysis. Int $J$ Syst Evol Microbiol 50, 1351-1371.

Felsenstein, J. (1985). Confidence limits on phylogenies: an approach using the bootstrap. Evolution 39, 783-791.
Guého, E., Smith, M. T., de Hoog, G. S., Billon-Grand, G., Christen, R. \& Batenburg-van der Vegte, W. H. (1992). Contributions to a revision of the genus Trichosporon. Antonie Leeuwenhoek 61, 289-316.

Guého, E., Improvisi, L., de Hoog, G. S. \& Dupont, B. (1994). Trichosporon on humans: a practical account. Mycoses 37, 3-10.

Herbrecht, R., Koening, H., Waller, K., Liu, L. \& Guého, E. (1993). Trichosporon infections: clinical manifestations and treatment. J Mycol Med 3, 129-136.

Ikeda, R., Yokota, M. \& Shinoda, T. (1996). Serological characterization of Trichosporon cutaneum and related species. Microbiol Immunol 40, 813-819.

Kimura, M. (1980). A simple method for estimating evolutionary rates of base substitutions through comparative studies of nucleotide sequences. J Mol Evol 16, 111-120.

Kurtzman, C. P. \& Robnett, C. J. (1997). Identification of clinically important ascomycetous yeasts based on nucleotide divergence in the $5^{\prime}$ end of the large-subunit (26S) ribosomal DNA gene. $J$ Clin Microbiol 35, 1216-1223.

Makimura, K., Murayama, S. Y. \& Yamaguchi, H. (1994). Detection of a wide range of medically important fungi by the polymerase chain reaction. J Med Microbiol 40, 358-364.

Middelhoven, W. J., Scorzetti, G. \& Fell, J. W. (1999). Trichosporon guehoae sp. nov., an anamorphic basidiomycetous yeast. Can J Microbiol 45, 686-690.

Middelhoven, W. J., Scorzetti, G. \& Fell, J. W. (2000). Trichosporon veenhuisii sp. nov., an alkane-assimilating anamorphic basidiomycetous yeast. Int J Syst Evol Microbiol 50, 381-387.

Nishiura, Y., Nakagawa-Yoshida, K., Suga, M., Shinoda, T., Guého, E. \& Ando, M. (1997). Assignment and serotyping of Trichosporon species: the causative agents of summer-type hypersensitivity pneumonitis. J Med Vet Mycol 35, 45-52.

Saitou, N. \& Nei, M. (1987). The neighbor-joining method: a new method for reconstructing phylogenetic trees. Mol Biol Evol 4, 406-425.

Sugita, T. \& Nakase, T. (1998a). Trichosporon japonicum sp. nov. isolated from the air. Int $J$ Syst Bacteriol 48, 1425-1429.

Sugita, T. \& Nakase, T. (1998b). Molecular phylogenetic study of the basidiomycetous anamorphic yeast genus Trichosporon and related taxa based on small subunit ribosomal DNA sequences. Mycoscience 39, 1-10.

Sugita, T., Nishikawa, A. \& Shinoda, T. (1994). Reclassification of Trichosporon cutaneum by DNA relatedness by using the spectrophotometric method and the chemiluminometric method. J Gen Appl Microbiol 40, 397-408.

Sugita, T., Nishikawa, A., Shinoda, T., Yoshida, K. \& Ando, M. (1995a). A new species, Trichosporon domesticum, isolated from the house of a summer-type hypersensitivity pneumonitis patient in Japan. J Gen Appl Microbiol 41, 429-436.

Sugita, T., Nishikawa, A., Shinoda, T. \& Kume, H. (1995b). Taxonomic position of deep-seated, mucosa-associated, and superficial isolates of Trichosporon cutaneum from trichosporonosis patients. J Clin Microbiol 33, 1368-1370.

Sugita, T., Nishikawa, A., Ikeda, R. \& Shinoda, T. (1999). Identification of medically relevant Trichosporon species based on sequences of internal transcribed spacer regions and construction of a database for Trichosporon identification. J Clin Microbiol 37, 1985-1993.

Sugita, T., Takashima, M., Ikeda, R., Nakase, T. \& Shinoda, T. (2000). Phylogenetic and taxonomic heterogeneity of Cryptococcus humicolus by analysis of the sequences of the internal 
transcribed spacer regions and $18 \mathrm{~S}$ rDNA, and the phylogenetic relationships of $C$. humicolus, $C$. curvatus, and the genus Trichosporon. Microbiol Immunol 44, 455-461.

Thompson, J. D., Higgins, D. G. \& Gibson, T. J. (1994). CLUSTAL W: improving the sensitivity of progressive multiple sequence alignment through sequence weighting, position-specific gap penalties and weight matrix choice. Nucleic Acid Res 22, 4673-4680.

Yarrow, D. (1998). Methods for the isolation, maintenance, classification and identification of yeasts. In The Yeasts, a Taxonomic Study, 4th edn, pp. 75-100. Edited by C. P. Kurtzman \& J. W. Fell. Amsterdam: Elsevier. 